\title{
Arbuscular mycorrhizal fungal colonization of Glycyrrhiza glabra roots enhances plant biomass, phosphorus uptake and concentration of root secondary metabolites
}

\author{
HongLing LIU ${ }^{1,2}$, Yong TAN ${ }^{3}$, Monika NELL ${ }^{2}$, Karin ZITTER-EGLSEER ${ }^{2}$, Chris WAWSCRAH ${ }^{2}$, \\ Brigitte KOPP ${ }^{2}$, ShaoMing WANG ${ }^{4 *}$, Johannes NOVAK ${ }^{1}$ \\ ${ }^{1}$ Normal College, Shihezi University, Shihezi 832000, China; \\ ${ }^{2}$ Institute of Applied Botany, University of Veterinary Medicine, Veterinaerplatz 1, A-1210 Wien, Austria; \\ ${ }^{3}$ College of Pharmacy, Shihezi University, Shihezi 832002, China; \\ ${ }^{4}$ College of Life Sciences, Shihezi University, Shihezi 832000, China
}

\begin{abstract}
Arbuscular mycorrhizal (AM) fungi penetrate the cortical cells of the roots of vascular plants, and are widely distributed in soil. The formation of these symbiotic bodies accelerates the absorption and utilization of mineral elements, enhances plant resistance to stress, boosts the growth of plants, and increases the survival rate of transplanted seedlings. We studied the effects of various arbuscular mycorrhizae fungi on the growth and development of licorice (Glycyrrhiza glabra). Several species of AM, such as Glomus mosseae, Glomus intraradices, and a mixture of fungi (G. mosseae, G. intraradices, G. cladoideum, G. microagregatum, G. caledonium and G. etunicatum) were used in our study. Licorice growth rates were determined by measuring the colonization rate of the plants by the fungi, plant dry biomass, phosphorus concentration and concentration of secondary metabolites. We established two cloned strains of licorice, clone 3 (C3) and clone 6 (C6) to exclude the effect of genotypic variations. Our results showed that the AM fungi could in fact increase the leaf and root biomass, as well as the phosphorus concentration in each clone. Furthermore, AM fungi significantly increased the yield of certain secondary metabolites in clone 3. Our study clearly demonstrated that AM fungi play an important role in the enhancement of growth and development of licorice plants. There was also a significant improvement in the secondary metabolite content and yield of medicinal compounds from the roots.
\end{abstract}

Keywords: licorice; arbuscular mycorrhizal fungi; phosphorus; medical compounds

Citation: HongLing LIU, Yong TAN, Monika NELL, Karin ZITTER-EGLSEER, Chris WAWSCRAH, Brigitte KOPP, ShaoMing WANG, Johannes NOVAK. 2014. Arbuscular mycorrhizal fungal colonization of Glycyrrhiza glabra roots enhances plant biomass, phosphorus uptake and concentration of root secondary metabolites. Journal of Arid Land, 6(2): 186-194. doi: 10.1007/s40333-013-0208-5

Licorice (Glycyrrhiza glabra) of the family Fabaceae is an herbaceous perennial, cross-pollinated plant (Olukoga and Donaldson, 1998). G. glabra roots and rhizomes are extensively used in herbal medicines for their emollient, anti-inflammatory, anti-viral, anti-oxidant, gastro-protective and anti-cancerous properties. G. glabra root extracts are also used in food, confectionery and pharmaceutical products, such as cough syrups and herbal supplements. Several studies have detailed the medicinal uses of G. glabra (Davis and Morris, 1991; Taka-hara and Watanabe, 1994; Arase et al., 1997; Barnes et al., 2007). The chemical constituents of the roots include several bioactive compounds, such as glycyrrhizin (up to 16\%), different sugars (up to 18\%), flavonoids, saponoids, sterols, starches, amino acids, gums and essential

*Corresponding author: ShaoMing WANG (E-mail: westwild@vip.sina.com)

Received 2013-06-06; revised 2013-09-23; accepted 2013-10-19

(C) Xinjiang Institute of Ecology and Geography, Chinese Academy of Sciences, Science Press and Springer-Verlag Berlin Heidelberg 2014 
oils. Glycyrrhizin is a water-soluble pentacyclic triterpenoid glycoside responsible for the sweetness of licorice, while aglycone is responsible for its medicinal properties and clinical applications in the treatment of spleen, sore throat, bronchitis, liver, kidney and ulcers (Kitagawa, 2002). However, the current wild licorice resources are dwindling as a result of excessive excavation, which threatens the ecological environment of the arid and semi-arid regions. Furthermore, the yearly worldwide licorice production is about $10 \times 10^{6}$ tons, of which almost $90 \%$ consumption can be attributed to China (Fu, 2004). Li et al. (2011) studied the effect of water deficit on root biomass and accumulation of secondary metabolites in licorice. They found that a weak water deficit augments the yield of root medicinal compounds without negatively affecting root growth and biomass. Akashi et al. (1999) isolated isoflavonoids from a licorice cell line that produces isoflavonoids upon elicitation. Although, these studies have shown that the production of isoflavonoids and other metabolites can be enhanced in licorice roots, there have been no studies to trigger an increase in shoot and root biomass.

AM fungal inoculation of soybean, corn, millet, trifoliate orange, rice and seventeen tropical legumes has demonstrated an improved economic impact on agriculture and horticulture (Vinayak and Bagyaraj, 1990; Tewari et al., 1993; Khalil et al., 1994; Secilia and Bagyaraj, 1994; Duponnois et al., 2001) by enhancing plant growth and yield (Bagyaraj, 1984; Jeffries, 1987; Akiyama and Hayashi, 2002). AM fungi are also known to impact the production of secondary metabolites in the roots of plants, such as Medicago sativa (Larose et al., 2002) and Cucumis sativus (Akiyama and Hayashi, 2002). Although these secondary metabolites are not directly involved in plant growth and development, they are a distinctive source of pharmaceuticals, food additives, flavor enhancers and various other industrial resources (Zhao et al., 2005). The biosynthesis of secondary plant metabolites in the roots can cause accumulation of flavonoids (Vierheilig et al., 1998a; Larose et al., 2002), triterpenoids (Akiyama and Hayashi, 2002), cyclohexanone 11 derivatives and apocarotenoids (Peipp et al., 1997; Vierheilig et al., 2000; Fester et al., 2002; Strack et al., 2003), phytoalexins (Sundaresan et al., 1993) and phenolic compounds (Grandmaison et al.,
1993). The mechanisms that initiate AM establishment also alter the secondary metabolism in roots (Larose et al., 2002), cause degradation of mycorrhizal structures inside the roots (Fester et al., 2002) and protect roots against pathogen invasion (Sundaresan et al., 1993; Volpin et al., 1994). These changes in plant roots upon AM establishment may affect the growth and development of a plant; however, this hypothesis has not been corroborated by past studies.

In this paper we explore whether the colonization of licorice roots by arbuscular mycorrhizal fungi (AMF) affects plant biomass, concentration of pharmacologically active compounds and phosphorus uptake from the soil. Based on review of previous studies, our hypothesis was that association of licorice roots and AMF would result in significant enhancement of root growth, which in turn would increase the concentration of medicinally important secondary metabolites in the roots.

\section{Material and methods}

\subsection{Biological material and in-vitro propagation}

Mature seeds of G. glabra were obtained from an adult plant grown in the medicinal plant garden of the Department of Pharmacognosy, University of Vienna. The seeds were surface sterilized in $30 \%$ ethanol for one minute, followed by a $30-\mathrm{min}$ treatment with aqueous sodium hypochlorite solution $(3.2 \%$ active chlorine). After three rinses with distilled water the seeds were transferred to test tubes $(165 \mathrm{~mm} \times 23 \mathrm{~mm})$ containing $13 \mathrm{~mL}$ of modified MS semisolid medium (1/2 MS) (Murashige and Skoog, 1962) lacking ammonium nitrate and with the other macronutrients at half strength, and containing $10 \mathrm{~g} / \mathrm{L}$ sucrose, $50 \mathrm{mg} / \mathrm{L}$ myo-inositol, $3 \mathrm{~g} / \mathrm{L}$ Gelrite (Roth, Germany) and 10.5 $\mu \mathrm{g} / \mathrm{L}$ indole-3-acetic acid (IAA; Sigma-Aldrich, USA). The $\mathrm{pH}$ of the media was adjusted to $5.7 \pm 0.1$ with $1 \mathrm{M}$ potassium hydroxide before autoclaving for $20 \mathrm{~min}$ at $121^{\circ} \mathrm{C}$. The cultures were maintained and multiplied in the growth chamber at $25 \pm 1^{\circ} \mathrm{C}$, under a 16 -h photoperiod provided by cool white fluorescent tubes ( 50 $\left.\mu \mathrm{mol} /\left(\mathrm{m}^{2} \cdot \mathrm{s}\right)\right)$. Subsequently, the seedlings were transferred to glass jars $(110 \mathrm{~mm} \times 60 \mathrm{~mm} \varnothing)$ with $40 \mathrm{~mL}$ of modified MS medium containing $30 \mathrm{~g} / \mathrm{L}$ sucrose, 100 $\mathrm{mg} / \mathrm{L}$ myo-inositol and $3 \mathrm{~g} / \mathrm{L}$ Gelrite, and supplemented with $5 \mu \mathrm{M}$ Kinetin (Sigma-Aldrich, USA). 
Seedlings were subcultured every 30 days by excising nodal segments and transferring the explants to a fresh medium. After 20 weeks of in-vitro propagation shoots of clone 3 and clone 6 were transferred to the modified MS medium for root formation. After four weeks, the rooted plantlets were transferred to pots containing an autoclaved mixture of peat and sand (2:1) and kept in a mist chamber at $80 \%$ initial relative humidity, which was gradually lowered to $50 \%$. Two months later the plantlets were transferred to greenhouse conditions.

\subsection{Growth conditions and experimental design}

The liquorice seedlings were transferred into pots ( 20 $\mathrm{cm}$ in diameter) containing an autoclaved substrate mixture of sand, soil and expanded clay $(1: 1: 1 ; \mathrm{v} / \mathrm{v} / \mathrm{v})$. The substrate mixture contained $1.12 \mathrm{mg} \mathrm{PO}_{4}{ }^{2-}$. Plants were grown in a random design in the greenhouse with a day/night cycle of $16 \mathrm{~h}$ at $22^{\circ} \mathrm{C}$ and $8 \mathrm{~h}$ at $19^{\circ} \mathrm{C}$ (relative humidity: 50\%-70\%). The seedlings were subject to five treatments (Table 1). As shown in Table 1, $5 \mathrm{~g}$ of the AM inoculum was added to each plantlet when the plantlets were transferred to the sterile substrate mixture. The plants were inoculated with three different AM fungi. The pure inoculum of $G$. mosseae (BEG 12) and G. intraradices (BB-E) were purchased from BIORIZE/AGRAUXINE (Quimper, France). It consisted of lyophilized mycorrhizal roots containing sporocarps, spores and hyphae of the particular fungus blended with silica sand. The inoculum 'Symbivit ${ }^{\mathbb{B}}$, was purchased from the company 'Symbio-m' (Lanskroun, Czech Republic) and consisted of 6 different Glomus species (G. mosseae, G. intraradices, $G$. cladoideum, G. microagregatum, G. caledonium and $G$. etunicatum). During the growth period of 7 months, the plants were watered with a nutrient solution (475 $\mathrm{mg} / \mathrm{L} \mathrm{Ca}\left(\mathrm{NO}_{3}\right)_{2}, 256 \mathrm{mg} / \mathrm{L} \mathrm{K}_{2} \mathrm{SO}_{4}, 136 \mathrm{mg} / \mathrm{L} \mathrm{MgSO}_{4}$, $70 \mathrm{mg} / \mathrm{L} \mathrm{MoO}{ }_{3}, 8 \mathrm{mg} / \mathrm{L} \mathrm{NH}_{4} \mathrm{NO}_{3}, 50 \mathrm{mg} / \mathrm{L} \mathrm{Fe}_{6} \mathrm{H}_{5} \mathrm{O}_{7} \cdot 3$ $\mathrm{H}_{2} \mathrm{O}, 1.3 \mathrm{mg} / \mathrm{L} \mathrm{Na} \mathrm{B}_{4} \mathrm{O}_{7} \cdot 4 \mathrm{H}_{2} \mathrm{O}, 1.5 \mathrm{mg} / \mathrm{L} \mathrm{MnSO}_{4} \cdot 4$ $\mathrm{H}_{2} \mathrm{O}, 0.6 \mathrm{mg} / \mathrm{L} \mathrm{ZnSO}_{4} \cdot 7 \quad \mathrm{H}_{2} \mathrm{O}, 0.54 \mathrm{mg} / \mathrm{L} \mathrm{CuSO}_{4} \cdot 5$ $\mathrm{H}_{2} \mathrm{O}, 0.028 \mathrm{mg} / \mathrm{L} \mathrm{Al}_{2}\left(\mathrm{SO}_{4}\right)_{3}, 0.028 \mathrm{mg} / \mathrm{L} \mathrm{NiSO}_{4} \cdot 7 \mathrm{H}_{2} \mathrm{O}$, $0.028 \mathrm{mg} / \mathrm{L} \mathrm{Co}\left(\mathrm{NO}_{3}\right)_{2} \cdot 6 \mathrm{H}_{2} \mathrm{O}, 0.028 \mathrm{mg} / \mathrm{L} \mathrm{TiO}_{2}, 0.014$ $\mathrm{mg} / \mathrm{L} \mathrm{LiCl}_{2}, 0.014 \mathrm{mg} / \mathrm{L} \mathrm{SnCl}_{2}, 0.014 \mathrm{mg} / \mathrm{L} \mathrm{KI}$ and $0.014 \mathrm{mg} / \mathrm{L} \mathrm{KBr})$ supplemented with $(36 \mathrm{mg} / \mathrm{L}$ $\mathrm{KH}_{2} \mathrm{PO}_{4}$ ) or without phosphorus.

\subsection{Estimation of the mycorrhizae colonization}

The harvested roots were gently washed to remove the soil. Roots and shoots were separated. The degree of mycorrhizae colonization (myc) was estimated using well-defined fresh root segments of $1 \mathrm{~cm}$ length, starting $7 \mathrm{~cm}$ downwards the shoot according to the ink staining method (Vierheilig et al., 1998) and the counting procedure of McGonigle et al. (1990). Shoots and remaining roots were dried at $35^{\circ} \mathrm{C}$. Dried roots were taken for estimation of pharmaceutical active compounds. Leaf and root samples were taken for phosphorus estimation.

Table 1 G. glabra seedlings inoculated with different arbuscular mycorrhizal fungi (AMF)

\begin{tabular}{llc}
\hline Treatment & \multicolumn{1}{c}{$\begin{array}{c}\text { Inoculate AMF } \\
\text { or not }\end{array}$} & $\begin{array}{c}\text { Fertilize phosphorus } \\
\text { or not }\end{array}$ \\
\hline C (control) & No & No \\
G.m & Yes (Glomus mosseae) & No \\
G.i & Yes (Glomus intraradices) & No \\
Sym & Yes (Symbivit) & No \\
P & No & Yes \\
\hline
\end{tabular}

\subsection{Phosphorus concentration}

Leaves and roots were ground, oven-dried for $4 \mathrm{~h}$ at $105^{\circ} \mathrm{C}$ and solubilized with a triple acid mixture for the analysis of $\mathrm{P}$ with the ammonium-vanadatemolybdate method. The results were expressed as $\mathrm{P}$ percentage of plant dry biomass.

\subsection{HPLC analysis of root compounds}

Ground root powder $(0.5 \mathrm{~g})$ was extracted with $10 \mathrm{~mL}$ methanol/water (80:20) solvent for an hour in an ultrasonic bath (cool). Filtered extracts were used for the determination of the compounds concentrations. The HPLC analysis was performed on a reverse phase $\mathrm{C} 18$ Symmetry ${ }^{\circledR}$ column $(4.0 \mathrm{~mm} \times 250 \mathrm{~mm}, 3 \mu \mathrm{m}$ pore size; Waters, USA) equipped with a Symmetry ${ }^{\circledR}$ C18 guard column. Detection was performed at $330 \mathrm{~nm}$ using a photodiode array detector (Waters, 996 PDA, USA). Mixture of $20 \mu \mathrm{L}$ microliters with $120 \mu \mathrm{g} / \mathrm{mL}$ mono-ammonium glycyrrhizinate was injected as standards for comparison.

\subsection{Statistical analysis}

Treatment effects were determined by one-way analysis of variance (ANOVA). Significant differences between treatments (indicated by different letters) were confirmed by Tukey's highest significant difference (HSD) test at a 5\% level of significance. All statistical 
analyses were performed with SPSS for Windows 15.0 .

\section{Results}

\subsection{Glycyrrhiza glabra clones from tissue culture}

G. glabra young stems were selected as explants to obtain 130 plantlets from two different plants of the female parent. Two cloned strains (clone 3 and clone 6) with sixty-five plantlets per strain were obtained (Fig. 1). Figures 1a, b, and c show the tissue culture stages, and Fig. 1d depicts the stage where the plantlets were transferred to the field plot. Figure 1e shows the stage of harvest time.

\subsection{AM colonization and biomass yield in clone 3 and clone 6}

Clone 3 (C3) showed a high degree of mycorrhizae colonization (78\%) with $G$. intraradices, and this was significantly higher than that observed with $G$. mossae or Symbivit (Table 2). Clone 6 (C6) also showed a higher degree of mycorrhizae colonization (myc) with $G$. intraradices as compared to the other two AMF treatments (Table 2). However, C3 and C6 showed the same degree of mycorrhizal colonization with $G$. intraradices. Moreover, G. mossae colonization of $\mathrm{C} 3$ and C6 clones was not significantly different from Symbivit. The dry weight (DW) of roots and shoots of licorice was affected by inoculation with arbuscular mycorrhizal (Fig. 2). In each clone, the DW of the inoculated treatment was higher than the control (C) and phosphorus (P) treatments. However, the shoot DW in C3 (inoculated treatment) was significantly higher than the control treatment. If clonal differences are not considered, C3+C6 (Fig. 3) show that shoot and root DW in each $G$. intraradices inoculated treatment was significantly higher than the control treatment.

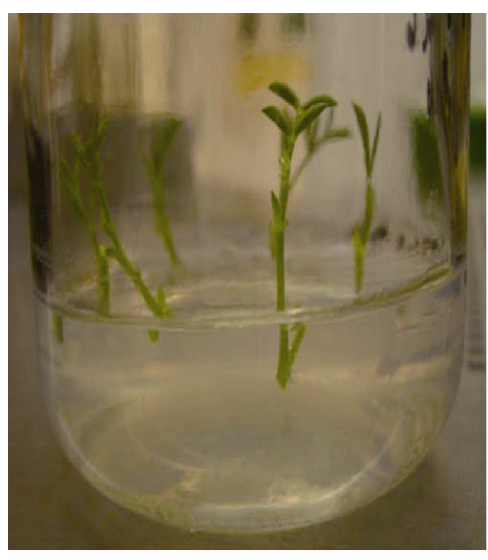

(a)

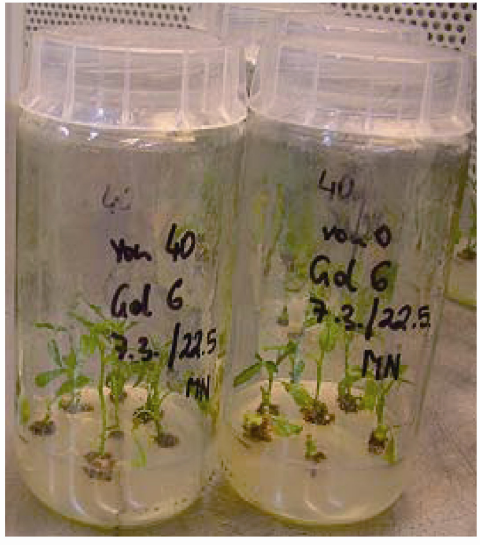

(b)

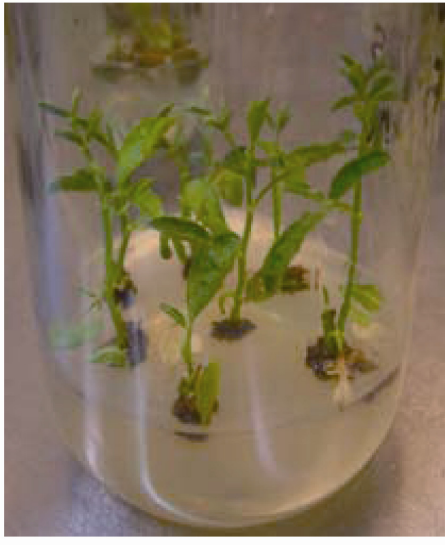

(c)

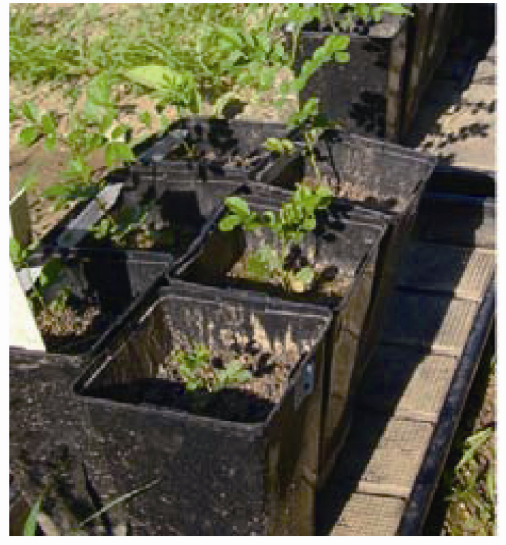

(d)

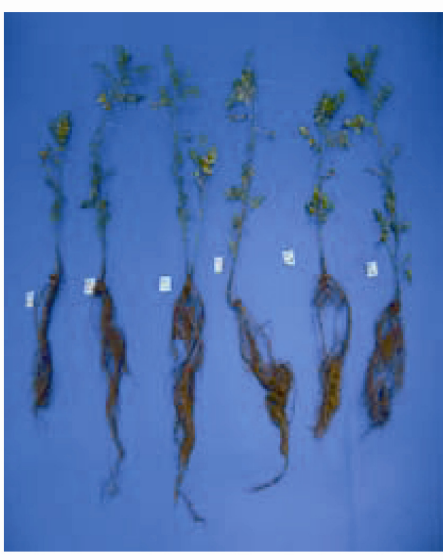

(e)

Fig. 1 Getting two different wild strains through tissue culture 
Table 2 Degree of mycorrhizae colonization (myc) of C3, C6, and C3+C6 of Glycyrrhiza glabra

\begin{tabular}{ccccccc}
\hline & & C (control) & Sym & G.m & G.i & P \\
\hline \multirow{2}{*}{$\begin{array}{c}\text { Degree of } \\
\text { myc (\%) }\end{array}$} & C3 & $0 \mathrm{a}$ & $64.67 \pm 3.43 \mathrm{~b}$ & $58.50 \pm 6.62 \mathrm{~b}$ & $78.67 \pm 2.92 \mathrm{c}$ & $0 \mathrm{a}$ \\
& $\mathrm{C} 6$ & $0 \mathrm{a}$ & $55.40 \pm 3.70 \mathrm{~b}$ & $61.00 \pm 1.64 \mathrm{~b}$ & $75.75 \pm 7.97 \mathrm{c}$ & $0 \mathrm{a}$ \\
\hline
\end{tabular}

Note: Different letters within one column represent significant differences at $P<0.05$ according to Tukey’s-b test. Mean \pm S.E.

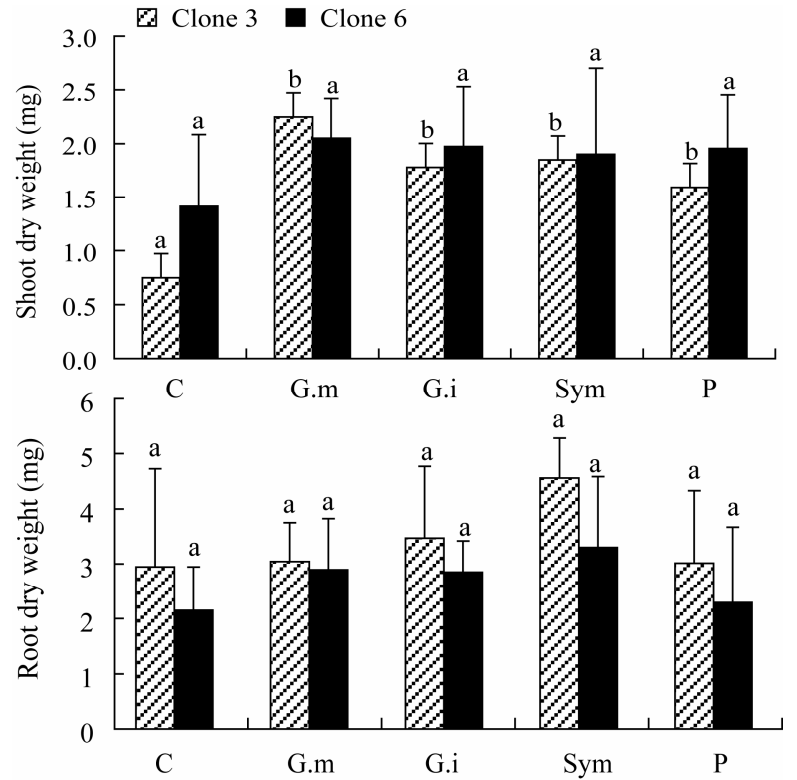

Fig. 2 Shoot and root dry weights of clone 3 and clone 6. Bars indicate Mean \pm S.E.

\subsection{Effect of AMF on phosphorus concentration}

The phosphorus concentration in the leaves and roots of licorice plants in each treatment was significantly higher than that in the control (Table 3). Furthermore, $P$ concentration in plants inoculated with AMF was significantly higher than that in plants treated with phosphorus fertilizer. Among the various treatments applied, the symbivit and $G$. mosseae treatments showed significantly higher $\mathrm{P}$ content than $G$. intraradices treatment. This trend was observed in all treatments and all clones tested including C3+C6.

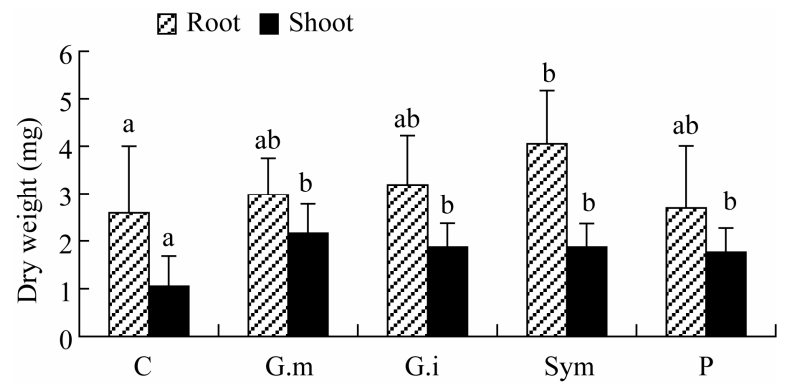

Fig. 3 Shoot and root dry weights of $\mathrm{C} 3+\mathrm{C} 6$. Bars indicate Mean \pm S.E.

\subsection{Secondary metabolites from licorice roots obtained through HPLC}

To study the effect of AM on secondary metabolites in licorice roots, we separated the root extracts via HPLC. Our results demonstrated the presence of 11 kinds of compounds, which were well separated on the reverse phase column. We quantified these compounds using the compound concentration on a root dry weight basis (Table 4). Five compounds (P1, P3, P7, P8 and

Table 3 Phosphorus concentration in leaves and roots of C3, C6 and C3+C6 of Glycyrrhiza glabra

\begin{tabular}{|c|c|c|c|c|c|c|}
\hline & & $\mathrm{C}$ (control) & Sym & G.m & G.i & $P$ \\
\hline \multirow{3}{*}{ Leaf $(g / k g)$} & $\mathrm{C} 3$ & $0.61 \pm 0.03 \mathrm{a}$ & $2.11 \pm 0.08 \mathrm{~d}$ & $1.94 \pm 0.11 \mathrm{~d}$ & $1.50 \pm 0.03 \mathrm{c}$ & $1.14 \pm 0.06 \mathrm{~b}$ \\
\hline & C6 & $1.04 \pm 0.15 \mathrm{a}$ & $1.90 \pm 0.11 \mathrm{c}$ & $1.67 \pm 0.15 b c$ & $1.29 \pm 0.22 \mathrm{ab}$ & $1.01 \pm 0.07 \mathrm{a}$ \\
\hline & $\mathrm{C} 3+\mathrm{C} 6$ & $0.81 \pm 0.09 \mathrm{a}$ & $2.01 \pm 0.07 \mathrm{~d}$ & $1.82 \pm 0.09 \mathrm{~d}$ & $1.42 \pm 0.09 \mathrm{c}$ & $0.90 \pm 0.10 \mathrm{~b}$ \\
\hline \multirow[t]{3}{*}{ Root (g/kg) } & $\mathrm{C} 3$ & $0.84 \pm 0.05 \mathrm{a}$ & $4.87 \pm 0.10 \mathrm{~d}$ & $4.28 \pm 0.24 \mathrm{~d}$ & $3.11 \pm 0.11 \mathrm{c}$ & $1.94 \pm 0.24 b$ \\
\hline & C6 & $1.27 \pm 0.08 \mathrm{a}$ & $4.66 \pm 0.17 \mathrm{c}$ & $4.38 \pm 0.05 \mathrm{c}$ & $2.51 \pm 0.58 \mathrm{~b}$ & $1.88 \pm 0.18 \mathrm{ab}$ \\
\hline & $\mathrm{C} 3+\mathrm{C} 6$ & $1.04 \pm 0.08 \mathrm{a}$ & $4.78 \pm 0.10 \mathrm{c}$ & $4.23 \pm 0.20 \mathrm{c}$ & $2.67 \pm 0.49 \mathrm{~b}$ & $1.91 \pm 0.15 b$ \\
\hline \multirow[t]{3}{*}{ Total P (g/kg DW) } & $\mathrm{C} 3$ & $2.21 \pm 0.29 \mathrm{a}$ & $3.05 \pm 0.29 \mathrm{a}$ & $3.47 \pm 0.53 \mathrm{a}$ & $4.56 \pm 0.30 \mathrm{a}$ & $3.01 \pm 0.54 \mathrm{a}$ \\
\hline & C6 & $2.15 \pm 0.35 \mathrm{a}$ & $2.90 \pm 0.42 \mathrm{a}$ & $2.85 \pm 0.25 \mathrm{a}$ & $3.30 \pm 0.64 \mathrm{a}$ & $2.30 \pm 0.61 \mathrm{a}$ \\
\hline & $\mathrm{C} 3+\mathrm{C} 6$ & $2.58 \pm 0.43 \mathrm{a}$ & $2.99 \pm 0.23 \mathrm{ab}$ & $3.19 \pm 0.31 \mathrm{ab}$ & $4.05 \pm 0.36 \mathrm{~b}$ & $2.69 \pm 0.40 \mathrm{ab}$ \\
\hline
\end{tabular}

Note: Different letters within one parameter represent significant differences at $P<0.05$ according to Tukey's-b test. 
Table 4 Compounds concentration of C3, C6 and C3+C6 of Glycyrrhiza glabra

\begin{tabular}{|c|c|c|c|c|c|c|}
\hline & & $\mathrm{C}$ (control) & Sym & G.m & G.i & $\mathrm{P}$ \\
\hline \multirow[t]{3}{*}{ P1 (mg/g DW) } & $\mathrm{C} 3$ & $0.20 \pm 0.01 \mathrm{a}$ & $0.27 \pm 0.01 \mathrm{~b}$ & $0.26 \pm 0.01 b$ & $0.25 \pm 0 \mathrm{~b}$ & $0.25 \pm 0.01 \mathrm{~b}$ \\
\hline & $\mathrm{C} 6$ & $0.16 \pm 0.04 \mathrm{a}$ & $0.26 \pm 0.01 \mathrm{a}$ & $0.19 \pm 0.05 \mathrm{a}$ & $0.24 \pm 0.03 \mathrm{a}$ & $0.23 \pm 0.02 \mathrm{a}$ \\
\hline & $\mathrm{C} 3+\mathrm{C} 6$ & $0.2 \pm 0.06 \mathrm{a}$ & $0.26 \pm 0.01 b$ & $0.24 \pm 0.01 b$ & $0.25 \pm 0.01 \mathrm{~b}$ & $0.24 \pm 0.01 \mathrm{~b}$ \\
\hline \multirow[t]{3}{*}{ P2 (mg/g DW) } & $\mathrm{C} 3$ & $0.74 \pm 0.07 \mathrm{a}$ & $0.58 \pm 0.04 \mathrm{a}$ & $0.68 \pm 0.09 \mathrm{a}$ & $0.74 \pm 0.07 \mathrm{a}$ & $0.84 \pm 0.13 \mathrm{a}$ \\
\hline & $\mathrm{C} 6$ & $0.61 \pm 0.14 \mathrm{a}$ & $0.58 \pm 0.04 \mathrm{a}$ & $1.02 \pm 0.2 \mathrm{a}$ & $0.69 \pm 0.25 \mathrm{a}$ & $0.78 \pm 0.07 \mathrm{a}$ \\
\hline & $\mathrm{C} 3+\mathrm{C} 6$ & $0.68 \pm 0.07 \mathrm{a}$ & $0.58 \pm 0.03 a$ & $0.82 \pm 0.1 \mathrm{a}$ & $0.72 \pm 0.1 \mathrm{a}$ & $0.81 \pm 0.07 \mathrm{a}$ \\
\hline \multirow[t]{3}{*}{ P3 (mg/g DW) } & $\mathrm{C} 3$ & $0.50 \pm 0.03 \mathrm{a}$ & $0.71 \pm 0.02 b$ & $0.67 \pm 0.02 b$ & $0.6 \pm 0.01 \mathrm{~b}$ & $0.62 \pm 0.03 b$ \\
\hline & $\mathrm{C} 6$ & $0.52 \pm 0.03 \mathrm{a}$ & $0.74 \pm 0.01 \mathrm{a}$ & $0.61 \pm 0.04 \mathrm{a}$ & $0.67 \pm 0.1 \mathrm{a}$ & $0.63 \pm 0.05 \mathrm{a}$ \\
\hline & $\mathrm{C} 3+\mathrm{C} 6$ & $0.51 \pm 0.02 \mathrm{a}$ & $0.72 \pm 0.01 \mathrm{c}$ & $0.64 \pm 0.02 b c$ & $0.6 \pm 0.04 \mathrm{bc}$ & $0.62 \pm 0.03 b$ \\
\hline \multirow[t]{3}{*}{ P4 (mg/g DW } & $\mathrm{C} 3$ & $0.79 \pm 0.05 \mathrm{a}$ & $0.92 \pm 0.08 \mathrm{a}$ & $0.9 \pm 0.04 \mathrm{a}$ & $0.91 \pm 0.01 \mathrm{a}$ & $0.94 \pm 0.06 \mathrm{a}$ \\
\hline & $\mathrm{C} 6$ & $0.67 \pm 0.13 \mathrm{a}$ & $0.94 \pm 0.03 \mathrm{a}$ & $0.76 \pm 0.06 \mathrm{a}$ & $0.95 \pm 0.15 \mathrm{a}$ & $0.87 \pm 0.09 \mathrm{a}$ \\
\hline & $\mathrm{C} 3+\mathrm{C} 6$ & $0.73 \pm 0.06 \mathrm{a}$ & $0.93 \pm 0.04 \mathrm{a}$ & $0.84 \pm 0.04 \mathrm{a}$ & $0.92 \pm 0.06 \mathrm{a}$ & $0.91 \pm 0.05 \mathrm{a}$ \\
\hline \multirow[t]{3}{*}{ P5 (mg/g DW) } & $\mathrm{C} 3$ & $0.50 \pm 0.02 \mathrm{a}$ & $0.56 \pm 0.01 \mathrm{a}$ & $0.47 \pm 0.02 \mathrm{a}$ & $0.49 \pm 0.02 \mathrm{a}$ & $0.46 \pm 0.04 \mathrm{a}$ \\
\hline & C6 & $0.52 \pm 0.09 \mathrm{a}$ & $0.49 \pm 0.03 \mathrm{a}$ & $0.45 \pm 0.03 \mathrm{a}$ & $0.47 \pm 0.05 \mathrm{a}$ & $0.42 \pm 0.03 \mathrm{a}$ \\
\hline & $\mathrm{C} 3+\mathrm{C} 6$ & $0.5 \pm 0.04 \mathrm{ab}$ & $0.53 \pm 0.02 b$ & $0.46 \pm 0.02 \mathrm{ab}$ & $0.4 \pm 0.02 \mathrm{ab}$ & $0.44 \pm 0.02 \mathrm{a}$ \\
\hline \multirow[t]{3}{*}{ P6 (mg/g DW) } & $\mathrm{C} 3$ & $1.86 \pm 0.13 \mathrm{a}$ & $2.15 \pm 0.14 \mathrm{a}$ & $2.08 \pm 0.08 \mathrm{a}$ & $2.20 \pm 0.01 \mathrm{a}$ & $2.07 \pm 0.14 \mathrm{a}$ \\
\hline & $\mathrm{C} 6$ & $1.65 \pm 0.25 \mathrm{a}$ & $2.29 \pm 0.07 \mathrm{a}$ & $1.81 \pm 0.17 \mathrm{a}$ & $2.29 \pm 0.38 \mathrm{a}$ & $2.05 \pm 0.2 \mathrm{a}$ \\
\hline & $\mathrm{C} 3+\mathrm{C} 6$ & $1.76 \pm 0.13 \mathrm{a}$ & $2.21 \pm 0.08 \mathrm{a}$ & $1.96 \pm 0.09 \mathrm{a}$ & $2.23 \pm 0.14 \mathrm{a}$ & $2.06 \pm 0.11 \mathrm{a}$ \\
\hline \multirow[t]{3}{*}{ P7 (mg/g DW) } & $\mathrm{C} 3$ & $0.6 \pm 0.03 \mathrm{ab}$ & $0.97 \pm 0.04 \mathrm{~d}$ & $0.73 \pm 0.05 \mathrm{bc}$ & $0.8 \pm 0.06 \mathrm{~cd}$ & $0.51 \pm 0.04 \mathrm{a}$ \\
\hline & C6 & $0.63 \pm 0.08 \mathrm{a}$ & $0.77 \pm 0.07 \mathrm{a}$ & $0.59 \pm 0.05 \mathrm{a}$ & $0.62 \pm 0.13 \mathrm{a}$ & $0.51 \pm 0.05 \mathrm{a}$ \\
\hline & $\mathrm{C} 3+\mathrm{C} 6$ & $0.62 \pm 0.04 \mathrm{a}$ & $0.88 \pm 0.05 \mathrm{c}$ & $0.67 \pm 0.04 \mathrm{ab}$ & $0.7 \pm 0.07 \mathrm{bc}$ & $0.51 \pm 0.03 \mathrm{a}$ \\
\hline \multirow[t]{3}{*}{ P8 (mg/g DW) } & $\mathrm{C} 3$ & $1.0 \pm 0.06 \mathrm{~b}$ & $1.37 \pm 0.06 \mathrm{c}$ & $0.99 \pm 0.08 b$ & $1.1 \pm 0.11 \mathrm{bc}$ & $0.72 \pm 0.08 \mathrm{a}$ \\
\hline & $\mathrm{C} 6$ & $1.01 \pm 0.16 \mathrm{a}$ & $1.06 \pm 0.12 \mathrm{a}$ & $0.76 \pm 0.07 \mathrm{a}$ & $0.87 \pm 0.17 \mathrm{a}$ & $0.7 \pm 0.07 \mathrm{a}$ \\
\hline & $\mathrm{C} 3+\mathrm{C} 6$ & $1.0 \pm 0.07 \mathrm{bc}$ & $1.23 \pm 0.08 \mathrm{c}$ & $0.89 \pm 0.06 \mathrm{ab}$ & $1.04 \pm 0.1 \mathrm{bc}$ & $0.71 \pm 0.05 \mathrm{a}$ \\
\hline \multirow[t]{3}{*}{ P9 (mg/g DW) } & $\mathrm{C} 3$ & $2.3 \pm 0.18 b$ & $2.83 \pm 0.17 b$ & $2.06 \pm 0.21 b$ & $2.54 \pm 0.24 b$ & $1.34 \pm 0.16 \mathrm{a}$ \\
\hline & $\mathrm{C} 6$ & $0.83 \pm 0.30 \mathrm{a}$ & $1.56 \pm 0.35 \mathrm{a}$ & $1.16 \pm 0.24 \mathrm{a}$ & $1.16 \pm 0.62 \mathrm{a}$ & $0.87 \pm 0.22 \mathrm{a}$ \\
\hline & $\mathrm{C} 3+\mathrm{C} 6$ & $1.6 \pm 0.29 \mathrm{ab}$ & $2.50 \pm 0.19 \mathrm{c}$ & $1.63 \pm 0.21 \mathrm{ab}$ & $2.2 \pm 0.24 b c$ & $1.36 \pm 0.12 \mathrm{a}$ \\
\hline \multirow[t]{3}{*}{ P10 (mg/g DW) } & $\mathrm{C} 3$ & $0.38 \pm 0.02 \mathrm{a}$ & $0.43 \pm 0.01 \mathrm{a}$ & $0.39 \pm 0.02 \mathrm{a}$ & $0.41 \pm 0.01 \mathrm{a}$ & $0.36 \pm 0.02 \mathrm{a}$ \\
\hline & $\mathrm{C} 6$ & $0.35 \pm 0.02 \mathrm{a}$ & $0.28 \pm 0.07 \mathrm{a}$ & $0.36 \pm 0.01 \mathrm{a}$ & $0.29 \pm 0.11 \mathrm{a}$ & $0.33 \pm 0.02 \mathrm{a}$ \\
\hline & $\mathrm{C} 3+\mathrm{C} 6$ & $0.36 \pm 0.01 \mathrm{a}$ & $0.40 \pm 0.01 \mathrm{a}$ & $0.38 \pm 0.01 \mathrm{a}$ & $0.40 \pm 0.02 \mathrm{a}$ & $0.34 \pm 0.02 \mathrm{a}$ \\
\hline \multirow[t]{3}{*}{ P11 (mg/g DW) } & $\mathrm{C} 3$ & $0.39 \pm 0.03 \mathrm{a}$ & $0.45 \pm 0.02 \mathrm{a}$ & $0.37 \pm 0.02 \mathrm{a}$ & $0.39 \pm 0.03 \mathrm{a}$ & $0.33 \pm 0.04 \mathrm{a}$ \\
\hline & $\mathrm{C} 6$ & $0.29 \pm 0.04 \mathrm{a}$ & $0.27 \pm 0.03 \mathrm{a}$ & $0.14 \pm 0.06 \mathrm{a}$ & $0.19 \pm 0.07 \mathrm{a}$ & $0.17 \pm 0.04 \mathrm{a}$ \\
\hline & $\mathrm{C} 3+\mathrm{C} 6$ & $0.34 \pm 0.03 \mathrm{a}$ & $0.36 \pm 0.03 a$ & $0.29 \pm 0.03 \mathrm{a}$ & $0.34 \pm 0.03 \mathrm{a}$ & $0.27 \pm 0.03 \mathrm{a}$ \\
\hline
\end{tabular}

Note: P1-P11 indicates different compounds. Different letters within one column represent significant differences at $P<0.05$ according to Tukey's-b test. Means \pm S.E.

P9) in C3 were influenced by AM. The levels of P1, P3 and P7 in plants inoculated with AMF were significantly higher than the control and phosphorus treatments. The levels of $\mathrm{P} 8$ and $\mathrm{P} 9$ in plants inoculated with AMF were not significantly different as compared to the control; however, P8 and P9 were significantly higher in plants subject to phosphorus treatment. Significant differences were not observed in C6 with each treatment. The results for a combina- tion of $\mathrm{C} 3+\mathrm{C} 6$ were similar to those observed for $\mathrm{C} 3$. Significant differences were not observed for different treatments in C6. In C3, the levels of P1, P3, P7, P8 and $\mathrm{P} 9$ treated with $G$. intraradices were significantly higher than those in other treatments. However, $\mathrm{C} 3+\mathrm{C} 6$ showed significantly higher levels of all compounds except P2 in response to G. intraradices. Significant differences were not observed for all the other treatments. 


\section{Discussion and conclusions}

\subsection{AM fungi colonization}

Licorice has a long history of medicinal use in Europe and Asia. The root extracts of licorice are used to treat a variety of illnesses ranging from common cold to liver diseases (Fiore et al., 2005). In China, licorice is considered a superior balancing or harmonizing agent and finds its way in several herbal supplements. It is also used as an important food additive and is used to make candy and other confectionary. The widespread use of this botanical has therefore caused large scale farming of this crop. Therefore, strategies to increase the supply of licorice by increasing either cultivation or plant biomass are highly desirable. The association of AMF with roots of various plants results in an increase in plant biomass and productivity (Duponnois et al., 2001; Akiyama and Hayashi, 2002). Recently, Birhane et al. (2012) showed that AMF can enhance photosynthesis, water use efficiency and growth of frankincense seedlings under pulsed water availability. Bao and Yan (2004) reported that wild licorice infected with AM fungi shows a 30\% colonization rate in the middle and western regions of Inner Mongolia, China. In the present study, the degree of licorice root colonization with various species of AM fungi (alone or in combination) was about $60 \%$. Our results also showed that the highest degree of mycorrhizal root colonization (myc) could be achieved with G. intraradices as compared to the other AM fungi in all the clones tested (Table 2). It has been speculated that AM fungi initiate a signaling cascade that results in colonization, and these events do not elicit any adverse defense reaction from the host (Gadkar et al., 2001). Therefore, AM symbiosis is probably a complex genetic mechanism that should be further studied to elucidate the possible factors involved in differential colonization of various plant roots by different species of AMF

\subsection{Phosphorus uptake}

Phosphorus is critical for plant growth, and is a component of the nucleic acid structure of plants and bio-membranes. Therefore, it is important in cell division and tissue development. Phosphorus is also involved in the energy metabolism of cells and is required for the biosynthesis of primary and secondary metabolites in plants (Marschner, 2002). Conse- quently, plants have evolved a range of strategies to increase P uptake and mobility (Marschner, 1995), the most common among which is AM symbiosis. In AMF symbiosis with plant roots, the enhanced uptake of phosphorus is attributed to the fungal partner, and the increase in phosphorus uptake by the colonized roots in turn leads to increased plant growth (Burleigh et al., 2002; Smith et al., 2003). The AM fungi and plant roots are closely integrated as a result of several years of coevolution (Smith and Read, 2008). Our study showed that the phosphorus concentration in the leaves and roots of inoculated plants was significantly higher in all of the inoculated plants than that in control (Table 3). Symbivit and G. mosseae treatments resulted in significantly higher $\mathrm{P}$ accumulation as compared to G. intraradices although the rate of colonization was better with the latter species $G$. intraradices. Phosphorus concentration was significantly higher in the inoculated plants than in the phosphorus fertilizer treatment. The addition of $P$ fertilizer is ineffective mainly because of the low solubility of phosphates of iron, aluminun, and calcium leading to lower soil concentrations and mobility (Schachtman et al., 1998). Perhaps, different species of AMF affect the solubility of these phosphates differently, resulting in the observed variations in $\mathrm{P}$ concentration. Furthermore, the replacement of $\mathrm{P}$ in the "depletion zone" does not keep pace with uptake (Smith et al., 2011). Leguminous plants have the capability to simultaneously associate with AM fungi as well as Rhizobium sp. and form both arbuscular mycorrhizae and root nodules. This tripartite symbiosis involving AM fungi, rhizobia and leguminous plants possibly results in better nutrient absorption from the soil (Lum, 2003; Gage, 2004). The molecular and genetic mechanism regarding this harmonious association is yet to be elucidated.

\subsection{Biomass yield of licorice}

AM fungi can help improve the biomass yield of plants by improving resistance and nutrient utilization of plants (Smith and Smith, 2003). This has been demonstrated in several plants such as tropical legumes, where inoculation with $G$. aggregatum resulted in a significant increase in plant growth (Dupponois et al., 2001). In the present study also, the association with AM fungi resulted in an increase in the dry weight of roots and shoots of licorice, and this 
increase was higher than that observed with direct phosphorus treatment of plants. Although this effect was more evident in $\mathrm{C} 3$ licorice, the root and shoot biomass yield in C6 licorice was also increased. However, the increase in C6 was not statistically significant as compared to the control and $\mathrm{P}$ treatments. This can be attributed to genotypic variations between the clones, which in turn may affect the symbiotic capability of the plant.

\subsection{Levels of secondary metabolites in licorice roots}

Organic compounds that are not essentially involved in the growth, development and reproduction of an organism are called secondary metabolites (Haslam, 1985). These natural compounds belong to different chemical groups, such as terpenes, phenols, alkaloids, glycosides and phenazines, and are often restricted in their occurrence and accumulation in species belonging to the same phylogenetic group. In general, secondary metabolites are involved in the reproduction processes (e.g. attraction of pollinators) and in the protection of plants against biotic (e.g. pathogens, herbivores) and abiotic (e.g. radiation, nutrient deficiency) stress. The colonization of plant roots by various fungi results in the accumulation of

\section{References}

Afreen F, Zobayed S M A, Kozai T. 2005. Spectral quality and UV-B stress stimulate glycyrrhizin concentration of Glycyrrhiza uralensis in hydroponic and pot system. Plant Physiology and Biochemistry, 43(12): 1074-1081.

Akashi T, Aoki T, Ayabe S. 1999. Cloning and functional expression of a cytochrome P450 cDNA encoding 2-hydroxyisoflavanone synthase involved in biosynthesis of the isoflavonoid skeleton in licorice. Plant Physiology, 121(3): 821-828.

Akiyama K, Hayashi H. 2002. Arbuscular mycorrhizal fungus-promoted accumulation of two new triterpenoids in cucumber roots. Bioscience, Biotechnology, and Biochemistry, 66(4): 762-769.

Araim G, Saleem A, Arnason J T, et al. 2009. Root colonization by an arbuscular mycorrhizal (AM) fungus increases growth and secondary metabolism of purple coneflower, Echinacea purpurea (L.) Moench. Journal of Agricultural and Food Chemistry, 57(6): 2255-2258.

Arase Y, Ikeda K, Murashima N, et al. 1997. The long-term efficacy of glycyrrhizin in chronic hepatitis $\mathrm{C}$ patients. Cancer, 79(8): 1494-1500.

Bao Y Y, Yan W. 2004. Arbuscular mycorrhizae and their structural types on common plants in grasslands of mid-western Inner Mongolia. Biodiversity Science, 12(5): 501-508. various secondary metabolites. Alterations in secondary metabolism have been linked to the mechanisms involved during the AM establishment (Larose et al., 2002), degradation of mycorrhizal structures inside the roots (Fester et al., 2002) or protection of roots against pathogens (Sundaresan et al., 1993; Volpin et al., 1994). Our study corroborates these results by showing that AM fungi affect the levels of secondary plant compounds. Furthermore, the effects of AM fungi colonization change with different genotypes. The AM fungi can be applied to enhance the content of secondary metabolites and further the agricultural yield of roots and aerial harvest products in medicinal plants.

\section{Acknowledgements}

The work was supported by the National Basic Research Program of China (2009CB825101), the Xinjiang Production and Construction Corps Technology Innovation Fund for Youth Project (2011CB02), the National Natural Science Foundation of China (31000730), the Chun Hui Project Item of Ministry of Education of China (Z2006-1-83023) and the Great Science and Technology Research Program of the Shihezi University (gxjs2012-zdgg06-02). Many thanks for the cooperation project from the University of Natural Resources and Life Sciences, Vienna.

Barnes J, Anderson L A, Phillipson J D, et al. 2007. Herbal Medicines. London: Pharmaceutical Press.

Burleigh S H, Cavagnaro T, Jakobsen I. 2002. Functional diversity of arbuscular mycorrhizas extends to the expression of plant genes involved in $\mathrm{P}$ nutrition. Journal of Experimental Botany, 53(374): 1593-1601.

Davis E A, Morris D J. 1991. Medicinal uses of licorice through the millennia: The good and plenty of it. Molecular and Cellular Endocrinology, 78(1): 1-6.

Duponnois R, Plenchette C, Bâ A M. 2001. Growth stimulation of seventeen fallow leguminous plants inoculated with Glomus aggregatum in Senegal. European Journal of Soil Biology, 37(3): 181-186.

Endre G, Kereszt A, Kevei Z, et al. 2002. A receptor kinase gene regulating symbiotic nodule development. Nature, 417(6892): 962-966.

Fester T, Hause B, Schmidt D, et al. 2002. Occurrence and localization of apocarotenoids in arbuscular mycorrhizal plant roots. Plant and Cell Physiology, 43(3): 256-265.

Fu Y J, Cao G. 2004. The Chinese Licorice. Beijing: Science Press.

Gadkar V, David-Schwartz R, Kunik T, et al. 2001. Arbuscular mycorrhizal fungal colonization. Factors involved in host recognition. Plant Physiology, 127(4): 1493-1499. 
Gage D J. 2004. Infection and invasion of roots by symbiotic, nitrogen-fixing rhizobia during nodulation of temperate legumes. Microbiology and Molecular Biology Reviews, 68(2): 280-300.

Grandmaison J, Olah G M, Van Calsteren M R, et al. 1993. Characterization and localization of plant phenolics likely involved in the pathogen resistance expressed by endomycorrhizal roots. Mycorrhiza, 3(4): 155-164.

Haslam E. 1985. Metabolites and Metabolism. New York: Clarendon Press.

Jeffries P, Rhodes L H. 1987. Use of mycorrhizae in agriculture. Critical Reviews in Biotechnology, 5(4): 319-357.

Khalil S, Loynachan T E, Tabatabai M A. 1994. Mycorrhizal dependency and nutrient uptake by improved and unimproved corn and soybean cultivars. Agronomy Journal, 86(6): 949-958.

Larose G, Chenevert R, Moutoglis P, et al. 2002. Flavonoid levels in roots of Medicago sativa are modulated by the developmental stage of the symbiosis and the root colonizing arbuscular mycorrhizal fungus. Journal of Plant Physiology, 159(12): 1329-1339.

Li W D, Hou J L, Wang W Q, et al. 2011. Effect of water deficit on biomass production and accumulation of secondary metabolites in roots of Glycyrrhiza uralensis. Russian Journal of Plant Physiology, 58(3): 538-542.

Lum M R, Hirsch A M. 2003. Roots and their symbiotic microbes: Strategies to obtain nitrogen and phosphorus in a nutrient-limiting environment. Journal of Plant Growth Regulation, 21(4): 368-382.

Marschner H. 1996. Mineral Nutrition of Higher Plants. London: Academic Press.

McGonigle T P, Miller M H, Evans D G, et al. 1990. A new method which gives an objective measure of colonization of roots by vesicular-arbuscular mycorrhizal fungi. New Phytologist, 115(3): 495-501.

Nell M, Vötsch M, Vierheilig H, et al. 2009. Effect of phosphorus uptake on growth and secondary metabolites of garden sage (Salvia officinalis L.). Journal of the Science of Food and Agriculture, 89(6): 1090-1096.

Olukoga A, Donaldson D. 1998. Historical perspectives on health The history of liquorice: the plant, its extract, cultivation, commercialisation and etymology. The Journal of the Royal Society for the Promotion of Health, 118(5): 300-304.

Secilia J, Bagyaraj D J. 1994. Evaluation and first-year field testing of efficient vesicular arbuscular mycorrhizal fungi for inoculation of wetland rice seedlings. World Journal of Microbiology and Biotechnology, 10(4): 381-384.

Smith S E, Smith F A, Jakobsen I. 2003. Mycorrhizal fungi can dominate phosphate supply to plants irrespective of growth response. Plant Physiology, 133(1): 16-20.

Smith S E, Read D. 2008. Mycorrhizal Symbiosis, $3^{\text {rd }}$ edition. London: Academic Press.

Strack D, Fester T, Hause B, et al. 2003. Review paper: Arbuscular mycorrhiza: Biological, chemical, and molecular aspects. Journal of Chemical Ecology, 29(9): 1955-1979.

Sundaresan P, Raja N U, Gunasekaran P. 1993. Induction and accumulation of phytoalexins in cowpea roots infected with a mycorrhizal fungus Glomus fasciculatum and their resistance to Fusarium wilt disease. Journal of Biosciences, 18(2): 291-301.

Takada K, Tomoda M, Shimizu N. 1992. Core structure of glycyrrhizan GA, the main polysaccharide from the stolon of Glycyrrhiza glabra var. glandulifera; anti-complementary and alkaline phosphataseinducing activities of the polysaccharide and its degradation products. Chemical and Pharmaceutical Bulletin, 40(9): 2487-2490.

Tewari L, Johri B N, Tandon S M. 1993. Host genotype dependency and growth enhancing ability of VA-mycorrhizal fungi for Eleusine coracana (finger millet). World Journal of Microbiology and Biotechnology, 9(2): 191-195.

Vierheilig H, Coughlan A P, Wyss U, et al. 1998. Ink and vinegar, a simple staining technique for arbuscular-mycorrhizal fungi. Applied and Environmental Microbiology, 64(12): 5004-5007.

Vierheilig H, Maier W, Wyss U, et al. 2000. Cyclohexenone derivative-and phosphate-levels in split-root systems and their role in the systemic suppression of mycorrhization in precolonized barley plants. Journal of Plant Physiology, 157(6): 593-599.

Viyanak K, Bagyaraj D J. 1990. Selection of efficient VA mycorrhizal fungi for trifoliate orange. Biological Agriculture and Horticulture, 6(4): 305-311.

Volpin H, Elkind Y, Okon Y, et al. 1994. A vesicular arbuscular mycorrhizal fungus (Glomus intraradix) induces a defense response in alfalfa roots. Plant Physiology 104(2): 683-689.

Zhao J, Davis L C, Verpoorte R. 2005. Elicitor signal transduction leading to production of plant secondary metabolites. Biotechnology Advances, 23(4): 283-333. 